\title{
Towards Professionalism in Music: Self-assessed Learning Strategies of Conservatory Music Students
}

ESA VIRKKULA ${ }^{* 1}$ AND SÄDE-PIRKKO NisSIL $\ddot{A}^{2}$

$\approx$ One of the current spearhead projects in Finnish education is learning to learn. Learning strategies have been examined from a variety of perspectives. They are policies that either promote or hinder learning. They are any behaviours or thoughts that facilitate encoding in such a way that knowledge integration and retrieval are enhanced. Strategies can be practiced and learnt.

Direct and indirect learning strategies formed the model of defining music students' self-assessed learning habits in this research. The strategies dealt with here are memory, cognitive, compensation, metacognitive, affective and social strategies. Critical thinking strategies as well as deep and surface learning strategies were also observed.

In this paper, a theoretical background and methodological solutions will first be presented. A significant finding comes from cross-professional collaboration of students, teachers, and professionals during the research period: it enhanced the use of strategies. Another finding, the profitable use of the workshop method, can be adopted by other fields of learning and make processes flexible and fruitful.

Keywords: critical thinking strategies, music education, musical expertise, vocational education, workshop

$1{ }^{\star}$ Corresponding Author. Oulu University of Applied Sciences, School of Vocational Teacher Education, Finland; Esa.Virkkula@oamk.fi.

2 Retired language teacher and teacher educator. 


\section{Na poti k profesionalnosti $v$ glasbi: samoocenjevanje učnih strategij študentov konservatorija za glasbo}

Esa VirkKula in Säde-PirkKo Nissilä

$\approx$ Eden izmed trenutno vodilnih projektov na področju vzgoje in izobraževanja na Finskem je učenje učenja. Učne strategije so preučevali $\mathrm{z}$ različnih perspektiv. Odločitve šolske politike lahko bolj ali manj spodbudno vplivajo na učenje. Gre za vedenje ali razmišljanje, ki spodbuja integracijo znanja in razvijanje spretnosti učenja. Učne strategije lahko vadimo in se jih lahko naučimo. $\mathrm{V}$ okviru te raziskave so neposredne in posredne učne strategije sestavljale model samoocenjevanja učnih navad študentov glasbe. Strategije, s katerimi smo se ukvarjali, so bile: spominske, kognitivne, kompenzacijske, metakognitivne, afektivne in socialne. Opazovali smo strategije kritičnega mišljenja pa tudi globinske in površinske učne strategije. $\mathrm{V}$ prispevku najprej predstavljamo teoretična ozadja in metodološke rešitve. Pomembna ugotovitev izhaja iz medsebojnega sodelovanja študentov, učiteljev in strokovnjakov v obdobju trajanja projekta, ki je pripeljalo do pogostejše uporabe učnih strategij. Tovrstno delavniško delo je mogoče koristno prilagoditi tudi za spodbujanje fleksibilnega in učinkovitega učenja na drugih področjih.

Ključne besede: strategije kritičnega mišljenja, glasbeno izobraževanje, glasbena sposobnost, poklicno izobraževanje, pedagoška delavnica 


\section{Introduction}

The dominance of behaviourism in human learning resulted in a total dependence on the external events as determinants of the processes and information transformation that take place in a learner. Much of this observation dealt with the extent to which a learner could avail him/herself of mnemonics (e.g. Bower, 1970; Paivio, 1969, 1971; Wood, 1967). These tasks were associated with laboratory research tasks. Interest was also focused on ecologically valid tasks (Weinstein, Zimmerman, \& Palmer, 1988).

The changes to constructivism and humanistic approaches have raised learning strategies for discussion. The change affected the ways in which learning strategies are conceptualised, the methods used to evaluate their acquisition and use, and procedures used to teach them (Dweck, 1999; William \& Thompson, 2008).

In music students' education learning strategies are needed e.g. in the context of practice where students might have a chance to participate in "authentic activity" with the support of skilful experts (Lebler, 2008; Brown et al., 1989). Professionals who support novices in this endeavour act as coaches and help students construct images of what skilful practice might be (Schön, 1987; Virkkula, 2016a). They make their knowledge and thinking visible to the learners (Heaton \& Lampert, 1993). Social interactions between the students and their teachers and mentors are vital for the students' learning, because it is through these interactions that the students obtain access to the experienced teachers' thinking and ways of knowing (Wenger, 1998). Recent research reports (Nissilä \& Virkkula, 2015; Virkkula \& Nissilä, 2014) reveal that the professional/ mentor was expected to give advice and to control learning. The professional's task in relation to students was intended to be an encouraging supervisor, a facilitator of learning, and a partner.

\section{Learning Strategies}

When attempting to understand different ways of learning, it is important to differentiate between cognitive, affective, and conative constructs and, further, appropriate strategies and levels of effort.

Psychology has traditionally identified and studied three components of mind: cognition, affect, and conation (Huitt, 1996; Tallon, 1997). Cognition is generally associated with the question of 'what'. It refers to the processes of knowing and understanding: encoding, storing, processing, and retrieving information. 
Affect asks the question 'How do I feel about this knowledge or information?' It refers to the emotional interpretation of perceptions, information or knowledge. It is generally associated with one's positive or negative attachment to people, objects and ideas.

Conation is associated with the issue of "why". It refers to the connection of knowledge and affect to behaviour and is the personal, intentional, deliberate, goal-oriented, or striving component of motivation, the anticipatory aspect of behaviour (Baumeister, Bratslavsky, Muraven, \& Tice, 1998; Emmons, 1986). It is closely associated with the concept of volition, defined as willpower, or the freedom to make choices about what to do (Kane, 1985; Mischel, 1996). It is critical if an individual intends to engage successfully in self-direction and self-regulation (Barrel, 1995).

Critical thinking, again, is purposeful, self-regulatory judgement that results in interpretation, analysis, evaluation and interference, as well as explanation of the evidential, conceptual, methodological, criteriological, or contextual considerations upon which that judgement is based. It affirms that every system is perfectly designed to get the expected results (Facione \& Gittens, 2011; Nissilä, 2010).

Self-regulation of learning usually refers to cognition and effort through cognitive, metacognitive, and resource management strategies (Ruohotie, 2000). Learners' conceptions show connection to the outcomes of their learning. If they have a conception of the necessity of fast progress, they are likely to adopt superficial learning strategies. If the tasks that need cognitive processing are regarded as challenges, it refers to good performance. If the challenge is neglected and the tasks are approached superficially in a state of mind that leads to overconfidence, the learning outcomes are poor. There seems to be a close connection between learners' concepts of themselves, their approach to learning, and their conception of their possibilities to regulate their learning, as well as their desire to belong to a certain group (Bandura, 1986; Hickey, 1997; Hickey \& Zuiker, 2012; Lave \& Wegner, 1991).

Perceived self-efficacy is defined as people's beliefs about their capabilities to produce designated levels of performance. People with high assurance of their capabilities approach difficult tasks as challenges rather than threats. In contrast, the learners who doubt their capabilities avoid difficult tasks, which they consider personal threats. They have low aspirations and weak commitment to the goals they choose to pursue. When facing difficult tasks they dwell on their personal deficiencies and adverse outcomes (Bandura, 1994; Bagozzi, 1992).

Metacognition refers to higher order thinking skills involving active control over the cognitive processes engaged in learning. Its central characteristics 
are awareness of thinking, sustained motivation and use of strategies. Skills such as planning how to approach a given learning task, monitor comprehension, and evaluate progress toward the completion of a task are metacognitive in nature (Bandura, 1986). According to Flavell (1979, 1987; also, Flavell, Miller, \& Miller, 1993), metacognition consists both of metacognitive skills and metacognitive knowledge. He divides knowledge into the variables of person, task and strategy.

Knowledge of person variables refers to general knowledge about how human beings learn and process information, as well as individual knowledge of one's own learning processes and their relationship to the requirements of the tasks. Knowledge about strategy variables includes knowledge about both cognitive and metacognitive strategies, as well as conditional knowledge about when and where it is appropriate to use such strategies. All variables are closely related to motivational components, such as self-efficacy, control beliefs and expectancy of success (Ruohotie, 2000).

Most definitions of metacognition include both knowledge and strategy components. Still, there are problems associated with using such definitions. One major issue involves separating what is cognitive from what is metacognitive. The distinction lies in how the information is used. Pintrich and McKeachie (2000) has stated that cognitive strategies are used to help an individual achieve a goal, while metacognitive strategies are used to ensure that the goal will be/ has been reached (Roberts \& Erdos, 1993).

Because cognitive and metacognitive strategies are closely intertwined and dependent upon each other, any attempt to examine one without acknowledging the other would not provide an adequate picture (Ruohotie, 2000).

\section{Defining Learning Strategies in This Paper}

Division into direct and indirect strategies was first used by Rebecca Oxford (1990) for second language learning. Her taxonomy is not generalisable to any situation, but is goal-specific and connected to general theoretical aspects of learning. It introduces direct and indirect strategies: direct ones act in the situation of learning and its outcomes; indirect one influence in the background (Appendix 1). Direct strategies can be compared to the actors of a drama, visible and observable on the stage. The latter represent the directors of the drama, their great influence being unseen, observable only through the actors. 


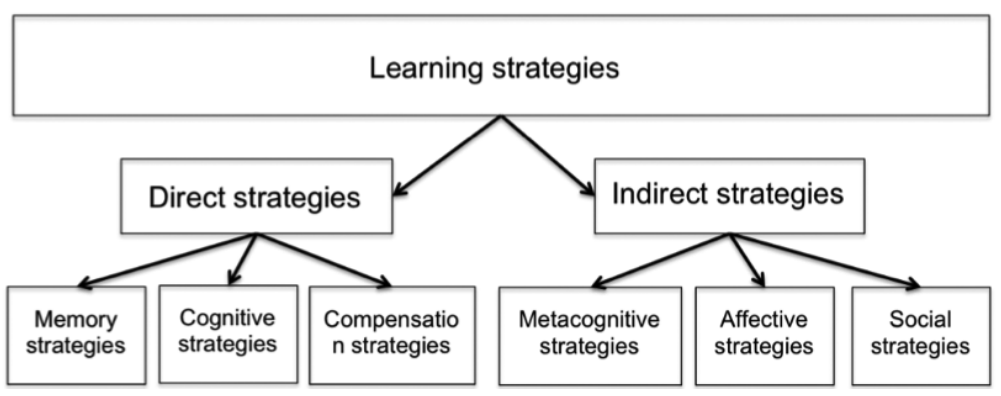

Figure 1. Classification of language learning strategies (Oxford, 1990).

Oxford presented her taxonomy in the following way:

- Direct Strategies

- Memory Strategies (code - MS)

MS 1 - Creating mental linkages

MS 2 - Applying images and sounds

MS 3 - Reviewing

MS 4 - Employing action

- Cognitive Strategies (CS)

CS 1 - Practicing

CS 2 - Receiving and sending messages

$\mathrm{CS}_{3}$ - Analysing and reasoning

CS 4 - Creating structure for input and output

- Compensation Strategies (C)

$\mathrm{C}_{1}$ - Guessing intelligently

$\mathrm{C} 2$ - Overcoming limitations in speaking and writing

- Indirect Strategies

- Metacognitive Strategies (MES)

MES 1 - Centring your learning

MES 2 - Arranging and planning your learning

MES 3 - Evaluating your learning

- Affective Strategies (AF)

AF 1 - Lowering your anxiety

AF 2 - Encouraging yourself

AF 3 - Taking your emotional temperature

- Social Strategies (S)

$S_{1}$ - Asking questions

$S_{2}$ - Cooperating with others

$\mathrm{S}_{3}$ - Empathising with others 
This classification system has been criticised for its problems in separating memory strategies from cognitive strategies, when one is a sub-category of the other, and for the inclusion of compensation strategies, which are connected to how a learner uses the language, rather than learns it (Macaro, 2006, 2010; Rose, 2012).

Due to the definitional indistinctiveness of Oxford's system, critics have argued that the whole field should be replaced with the psychological concept of self-regulation. However, some critics argue that self-regulation and language learning strategies measure different parts of the learning process and thus can be used in tandem to observe a more accurate picture of how learning takes place. The terms cognitive and metacognitive strategies remain common in strategy research, but others related to managing a learner's own affective state or social environment have been examined under the umbrella term of self-regulation.

After all critique and re-reflection, Oxford's taxonomy seems to match well with the material of music students' ways of learning. One minor argument for it is that languages and music are both expressive by nature and thus comparable in this aspect. Learning strategies have naturally strong links to the fields of self-directed learning, and learner autonomy (see Deci \& Ryan, 1985; Nissilä, 1999), as they share core notions of independent learning, learnercenteredness, and the necessity for learners to exercise responsibility for their learning, also in music workshops (Lebler, 2008; Virkkula, 2017).

\section{The Aim, Research Methods, and Material of this Study}

This study concerns music education and vocational music students' selfobserved learning strategies. For the research, a special intervention was arranged: during 2003-2011, 11 popular and jazz music workshops of 6-8 weeks were organised in the Conservatory of Oulu in Finland with four to eight participants in each workshop. Professional musicians were invited to practice for a concert with the students. The regular teachers acted as tutors. Each workshop started with joint pre-planning and goal setting in which the music theme and challenges in respect to the students' skills were discussed. Tasks and preparation work were agreed on. The students defined their personal developmental tasks in the workshop and wrote them in structured forms. After the workshops and concerts, the students $(\mathrm{N}=62)$ wrote about their experiences in their reflection forms guided by the following themes: Describe your cooperation with the professional musician! What did you learn in the workshop? What could you have done in another way? (Nissilä \& Virkkula, 2015; Virkkula, 2016a, 2016b). 
For the deep analysis 20 students' documents were chosen randomly, while the total of 62 yielded material for analysing deep and surface learning strategies.

The aim of the research was to determine how music students perceive their learning and how able they are to guide, assess and verbalise it. Another purpose was to observe music students' critical thinking skills. The research questions were the following:

1. What kind of learning strategies were observed in the music students' descriptions of learning?

2. How consciously did the music students utilise learning strategies in the music workshops?

3. What were the music students' most essential learning experiences in the workshop work and performances according to their self-assessment?

The research approach was a qualitative case study supported by some quantitative data. The data sets were (1) structured workshop plans in which students outlined their learning goals and (2) written descriptions of their experiences in the workshops. The data sources were complementary and yielded detailed experiential information expressed by the participants. Student statements were classified according to the application of Oxford's taxonomy (see Appendix 1) in which language learning terms were replaced by those of music learning. The material was also analysed according to the principles of deep and surface learning, as well as those of critical thinking strategies.

To analyse the data, each relevant passage was read and the statements were isolated which captured the meaning expressed by the participant. These units ranged in lengths from a few words to a paragraph. Thematic patterns were developed that would aid in the construction of a thick description of the experience. The variation of individual conceptions of the experiences was given attention. The descriptions were arranged to give meanings to the themes. The quotes given show the identity numbers of the research persons.

The trustworthiness was developed through two researchers reading the texts and the use of a critical colleague for discussing interpretations. Through the prolonged engagement with the participants, the truth value was sought to be established (Moschovich \& Brenner, 2000; Patton, 1990).

\section{Outcomes}

The definitions and list of music learners' strategies were created to suit music learning processes. The terms were given field-specific titles. 


\section{Cognitive and metacognitive learning strategies}

The following table presents the deep analysis findings of direct and indirect strategies of 20 randomly chosen music students.

Table 1

The strategies used by vocational music students

\begin{tabular}{|c|c|c|c|c|c|c|c|c|c|c|}
\hline $\begin{array}{l}\text { DIRECT } \\
\text { STRATEGIES }\end{array}$ & Code & a) & b) & c) & d) & e) & f) & g) & $\begin{array}{l}\text { Statements } \\
\text { in total } \\
(F=476)\end{array}$ & $\begin{array}{l}\text { Per cent of total } \\
\text { statements } \\
(F=100)\end{array}$ \\
\hline \multirow{4}{*}{ Memory } & MS 1 & 17 & 4 & 4 & & & & & 25 & 5.3 \\
\hline & MS 2 & 20 & 3 & 3 & 3 & & & & 29 & 6.1 \\
\hline & MS 3 & 2 & & & & & & & 2 & 0.4 \\
\hline & MS 4 & 1 & 1 & & & & & & 2 & 0.4 \\
\hline \multirow{4}{*}{ Cognitive } & CS 1 & 20 & 20 & 13 & 2 & & & & 55 & 11.6 \\
\hline & CS 2 & 5 & 7 & & & & & & 12 & 2.5 \\
\hline & $\mathrm{CS} 3$ & 7 & 4 & 6 & 6 & 4 & 9 & & 36 & 7.6 \\
\hline & CS 4 & & & 1 & & & & & 1 & 0.2 \\
\hline \multirow{3}{*}{ Compensation } & C 1 & 10 & 1 & & & & & & 11 & 2.3 \\
\hline & $C 2$ & & 20 & & & 3 & & & 23 & 4.8 \\
\hline & & & & & & & & & $f=196$ & 41.2 \\
\hline \multicolumn{11}{|l|}{ INDIRECT } \\
\hline STRATEGIES & MES 1 & 3 & 20 & 16 & & & & & 39 & 8.2 \\
\hline \multirow[t]{3}{*}{ Metacognitive } & MES 2 & 20 & 15 & 20 & 20 & 20 & 10 & & 105 & 22.1 \\
\hline & MES 3 & 3 & 20 & & & & & & 23 & 4.8 \\
\hline & AF 1 & & & & 9 & & & & 9 & 1.9 \\
\hline \multirow[t]{3}{*}{ Affective } & AF 2 & 6 & 4 & 20 & & & & & 30 & 6.3 \\
\hline & AF 3 & & & 20 & 2 & 6 & & & 28 & 5.9 \\
\hline & S 1 & & & & & & & & & 0.0 \\
\hline \multirow[t]{4}{*}{ Social } & S 2 & 8 & 14 & & & & & & 22 & 4.6 \\
\hline & S 3 & 2 & 2 & 20 & & & & & 24 & 5.0 \\
\hline & & & & & & & & & $f=280$ & 58.8 \\
\hline & & & & & & & & & $F=476$ & 100 \\
\hline
\end{tabular}

Note. Codes in vertical lines refer to sub strategies. Horizontal $a-f$-codes refer to functions within sub strategies. In the following, the students ' quoted are referred to with their research numbers. $\mathrm{MS}=$ memory strategies; $\mathrm{CS}=$ cognitive strategies; $\mathrm{C}=$ compensation strategies; $\mathrm{MES}=$ metacognitive strategies; $A F=$ affective strategies; $\mathrm{S}=$ social strategies. 
- $\quad$ Direct strategies $(41.2 \%)$

Memory strategies (MS 1 - 4)

Explanations:

MS 1: Grouping, associating, replacing earlier learnt with new: a) grouping b) associating c) replacing earlier learnt habits with new

MS 2: Using imagery, musical mapping, using key triggers, representing sounds in memory: a) using imagery b) musical mapping c) using key triggers $\mathrm{d}$ ) representing sounds in memory

MS 3: structured reviewing, structured arranging music: a) structured reviewing $b$ ) structured arranging music

MS 4: Using physical sensation, using mechanical techniques

(MS 3/a) I had earlier heard about a half of the programme, and when I heard that there would be familiar pieces, I was able to prepare myself. (3)

$\left(M_{3} 3 / b\right)$ I have collected an idea file about 2 years and practiced licks from there. This acts as a link between the theoretical world of the school and my own musical world. (17)

Cognitive strategies (CS $1-4)$

Explanations:

CS 1: repeating, formally practicing with sounds and training, recognising formulas and patterns, recombining or composing my own music, practicing naturalistically; a) repeating b) formally practicing with sounds \& training c) recognising formulas and patterns d) recombining or composing one's own music e) practicing naturalistically

CS 2: getting the idea quickly, using resources for communication through music; a) getting the idea quickly b) using resources for communication through music

CS 3: reasoning deductively, analysing expressions, analysing contrastively (across models), translating music expressions to meanings, transferring (one skill/expression/ tradition) to another, composing; a) reasoning deductively, b) analysing expressions, c) analysing contrastively (across models), d) translating music expressions to meanings, e) transferring (one skills/ expressions/ tradition to another), f) composing CS 4: taking notes, summarising, highlighting: a) taking notes, b) summarising, c) highlighting

(CS $1 / c)$ It is good that the music styles are dealt with in the workshops, because you can concentrate on one genre properly. (10) 
(CS 1/d) I was prepared to compose and arrange my own piece. By practicing the programme and improvisation. (16)

(CS $3 / a, c)$ In the group we talked of the theme and the pieces of the concert (era/genre). In the genre questions, we smoothed down in non- 'jazz' pieces. So, we didn't follow the recorded versions exactly, but made also our own solutions. (4)

(CS 3/d) The piano is a good instrument in an orchestra to strengthen other themes, since it has a strong attack. Although it is not very audible, its effect is remarkable. (20)

\section{Compensation strategies $\left(C_{1}-2\right)$}

Explanations:

C 1 using clues from music, using clues from personal experience; a) using clues from music, b) using clues from personal experience

C 2 switching to familiar ways of presentation, getting help, avoiding playing partially or totally, selecting the topic, adjusting playing, clever inventions, paraphrasing; a) switching to familiar ways of presentation, b) getting help, c) avoiding playing partially or totally, d) selecting the topic, e) adjusting playing, f) clever inventions, g) paraphrasing

(C 1/b) In music all experiences have direct influence on practice. (3)

(C 2/e) The stemmas of background songs were picked from a cd, they were changed a little and practiced a lot. It was fine to see how the professional musician built the pieces gliding ... gave also attention to students' ideas. (14)

\section{- $\quad$ Indirect strategies $(58.8 \%)$}

Metacognition, affection and social aspects are included in this group of strategies.

Metacognitive strategies (MES $1-3$ )

Explanations:

MES 1: overviewing and linking with already known material, paying attention, delaying expression to focus on listening; a) overviewing and linking with already known material, b) paying attention, c) delaying expression to focus on listening

MES 2: finding out about music learning, organising learning, setting goals and objectives, identifying the purpose of the task, planning for the presentation of the task, seeking opportunities to practice in or for life; a) finding out about music learning, b) organising learning, c) setting goals and objectives, d) identifying the purpose of the task, e) planning for the presentation of the task, f) seeking opportunities to practice in or for work life 
MES 3: self-monitoring, self-evaluating; a) self-monitoring, b) self-evaluating

(MES 2/c) I was allowed to influence the workshop. I got my ideas through in the right place. (6)

(MES 2/b-f) In the workshop you get, first of all, experience for field work; when you have three days' time to make the whole function with unfamiliar people, you only have to do so. You'll get more familiar with the core of the matter, when you practice intensively $6 \mathrm{~h} /$ a day. (13)

(MES $3 / a-b)$ I learnt to play so simply that I can listen more, hear myself as part of the band. (3)

$(M E S$ 3/b) (IC/2) My aim was to get myself through that all with honour, and it went then quite well. Later on, I felt that I gave all my best and did all that I could. (18)

Affective strategies $\left(A F_{1}-3\right)$
Explanations:

AF 1: using progressive relaxation, deep breathing or mediation, listening to sounds from nature, listening to others playing/ adaptation to the shared feeling, using laughter; a) using progressive relaxation, deep breathing or meditation, b) listening to sounds from nature, c) listening to others playing/ adaptation to the shared feeling, d) using laughter

AF 2: making positive statements, taking risks wisely, rewarding oneself; a) making positive statements, b) taking risks wisely, c) rewarding oneself

AF 3: listening to one's body, using a checklist, writing a learning diary, discussing one's feelings with somebody else, sharing attitudes; a) listening to one's body, b) using checklists, c) writing a learning diary, d) discussing one's feelings with somebody else, e) sharing attitudes

(AF 2/a) Cooperation with the visiting professional was really fine. No prima donna performances ... suitable amount of guidance and ideas, but nothing such as would have caused the feeling of inferiority. (11)

$(A F 2 / b)$ Surprisingly I learnt how to cool down the nerves, when 15 minutes before the first concert I had to solder the loosened cable of the bass ... (20)

(AF 2/c) In a concert everyone wants to give their best, so they have to work for it. (3) The concert is a reward of the work (all)

(AF $3 / d-e)$ The workshop develops communication skills with other band members. (3) 
Social strategies $\left(S_{1}-3\right)$

Explanations:

S 1: Asking for clarification or verification, asking for correction; a) asking for clarification or verification, b) asking for correction

S 2: cooperating with peers, cooperating with professionals; a) cooperating with peers, b) cooperating with professionals

S 3: developing cultural understanding, becoming aware of others' thoughts and feelings, sharing thoughts and intentions, playing in an orchestra; a) developing cultural understanding, b) becoming aware of others' thoughts and feelings c) sharing thoughts and intentions, playing in an orchestra

(S 2/a) I learnt more and more to listen to the others and appreciate the input of the others in the band. (15)

$\left(S_{2} / b\right)$ In the presence of a really experienced professional you feel how your attitude to jazz and other music like it gets deeper. Working was motivating. (3)

$\left(S_{3} / a\right)$ It was fine to talk and practice jazz more in the philosophical sense than theoretical. (16)

$\left(S_{3} / b-c\right)$ I learnt to get along with people having different opinions ... it is interesting to get new views from a person who has already worked years in the field of the music genre in question. A bonus is his positive attitude also to cooperation. (13)

In the next passage, the material examined above through Oxford's classification is observed from another point of view: that of critical thinking.

\section{Critical thinking strategies}

Efforts were taken to distinguish between the cognitive or epistemological aspect and the emotional, affective, motivational, and psychodynamic aspects. The following findings are divided into six skills: intellectual, perception, self-control, individuality, social, and motivational skills to represent critical thinking strategies (cf. Anderson et al., 2001; Soden \& Pithers, 2001; Tiruneh et al., 2014).

Intellectual skills reveal rational, systematic and analytical thinking, problem solving, change of perspective, skills in diagnostics, evaluation and planning, centring on the individual's capacity for rational behaviour.

It is good that the music styles are dealt with in the workshops, because you can concentrate on one genre properly. (10)

It was fine to talk and practice jazz more in the philosophical sense than theoretical. (16) 
Perception skills concern precise sense perception, typically including precision in observation and interpretation:

Synthesiser parts suitably scattered give a good technical added colour and counterweight to the rich-sounding world of the orchestra. It is well suited to describe the 'cold and technical' world of Bond films being present in Bond movies. (20)

Self-control skills cover definitions such as responsibility, reliability, perseverance, accuracy, ability to concentrate, quality orientation, centring on the individual's inclinations, and capacity to act in accordance with general instructions.

Surprisingly I learnt how to cool down my nerves, when 15 minutes before the first concert I had to solder the loosened cable of the bass ... (20)

Individuality skills cover independence, self-confidence, and creativity - centring on the individual's ability to act alone, especially in unforeseen situations.

I have collected an idea file about 2 years and practiced licks from there. This acts as a link between the theoretical world of the school and my own musical world. (17)

Social skills concern co-operation and communication abilities, congeniality, and sociability concerning the individual's ability to interact with others.

I learnt more and more to listen to the others and appreciate the input of the others in the band. (15)

Motivational skills cover initiative, dynamism, drive, openness, keenness to learn and adaptability, and concentrate on the individual's potential to keep up with and contribute to the development (sometimes called flexibility).

The concert is a climax to which all the project aims. In a concert, everyone wants to give their best, so they have to work for it. (3)

This study shows that knowledge structures and schemes were developed through cognitive processes, while affective experiences developed emotional patterns. The cognitive and emotional patterns seemed to be difficult to keep separate. For that reason, although the students were obviously able to observe critical thinking strategies consciously, they did not deal with them very analytically (research question 2). In general, critical thinking skills/ strategies seemed to increase through the process of education (Nissilä, 2010).

\section{Deep and surface learning strategies}

To summarise, the overall approach to the strategies and critical thinking skills was examined by observing the learning approaches of 62 students. Deep learning involves critical analysis of innovative ideas, linking them to already known concepts and principles so that this understanding can be used for 
problem solving in new, unfamiliar contexts (Biggs \& Tang, 2011; Lublin, 2003).

The documents of 62 students revealed that none of them showed superficial approaches. All did their best to prepare for the workshops to gain as much as possible from them. During the workshops, they also showed an amazing conscientiousness. The ones who were less advanced in skills were willing to use their time for interminable practices to be able to adopt all skills and knowledge available:

In the beginning, the project felt nearly insurmountable because of the challenging pieces that I happened to get. Then I set myself very moderate goals and also reached them ... The project was very rewarding even with all its feelings of upheaval. I learnt technically new skills just because it was necessary for performing the task. Now afterwards it is easy to smile at that wailing and gnashing of teeth. I did it!! (22)

\section{Conclusion}

The aim of this study was to explain music students' ability to perceive and assess their learning. The aim was formed into three research questions: 1) What kind of learning strategies were observed in the music students' descriptions of learning, 2) How consciously did the music students utilise learning strategies in the music workshops, and 3) What were the music students' most essential learning experiences in the workshop work and performances according to their self-assessment? The research questions guided the analysis of the data available, the theoretical research being connected to learning strategies (e.g. Oxford, 1990).

From the viewpoint of the first research question, the data analyses reveal that the use of both cognitive and metacognitive strategies was nearly equal among the vocational music students (41.2\%, vs 58.8\%). Recent theories of learning speak of learner autonomy, self-directed learning, self-regulated learning, or independent learning, as well as of problem based learning and active learning. They are not only examples and a matter of cognitive skills and processes, but also have an emotional and social nature. They require metacognitive skills and strategies to be fully functional (Deci \& Ryan, 2014; Nissilä, 1999).

Examining the results more closely reveals that direct strategies collected 196 statements (41.2\%), including statements of cognitive strategies (104), memory strategies (58) and compensation strategies (34). Indirect strategies, i.e. metacognitive, affective and social strategies collected 280 statements, $(58,8 \%)$. Metacognitive strategies dominated the data of indirect strategies (167), while affective summed up to 67 and social to 46 statements. 
In light of the second research question, in the subclass of cognitive strategies (direct strategies) two conscious learning habits dominated: 1) 'repeating, formally practicing with sounds \& training, recognising formulas and patterns, recombining or composing own music', and 2) 'reasoning deductively, analysing expressions, analysing contrastively (across models), translating music expressions to meanings, transferring (one skill/ expression/ tradition) to another and composing. Among memory strategies grouping, associating, replacing earlier habits with new as well as structured reviewing and structured arranging music were used most often and consciously. Compensation strategies collected the least of statements in the direct strategies group.

Of metacognitive strategies, the most frequently referred to was 'finding out about music learning, organising learning, setting goals and objectives, identifying the purpose of the task, planning for the presentation of the task and seeking opportunities to practice in or for work life. The next biggest class was "overviewing and linking with already known material, paying attention and delaying expressions to focus on listening" followed by 'self-monitoring and self-evaluating'. Among affective strategies 'making positive statements and sharing attitudes' was mentioned only in a minority of comments. No comments were directed e.g. to the ways that are popular in other contexts, viz. 'relaxation, deep breathing, meditation, laughing or to listening to one's body'. Instead, reflective practices were well adopted: all students wrote reflective learning diaries during their studies and thought that they were rewarded in the concert, which closed the workshop period (58 statements). Social strategies collected 46 statements out of which 'developing cultural understanding, becoming aware of the others' thoughts by playing together' amounted to 24 statements and 'cooperating with peers and cooperating with professionals' rose up to 22 statements. Being rewarded by an audience might also belong to this subclass, but it was placed in affective strategies of 'rewarding oneself'. This is a question of interpretation. The researchers thought that in the end the reward touched emotions and was personally affective.

Availing oneself of direct and indirect strategies shows that the overall mastering of strategies is at an appropriate, even surprisingly great level among the music students concerned (research question 1). Part of them were consciously used to it, and it seemed to form part of their habitual practices. Deep and surface learning and critical thinking strategies were analysed separately from the taxonomy. Critical thinking skills were advanced. The outcome produced another, compatible perspective for the results (research question 2).

In opposite to the pre-conceptions of the authors, the rewarding experiences were both cognitive and metacognitive not only emotional and social. 
The feeling of success in the concert was shared by everybody. The experience of learning new things and overcoming individual difficulties brought joy as did the notion of the utility of their own earlier efforts. Working in a team with experts brought the feeling of self-efficacy (research question 3 ).

To have a wide, combinational perspective for the results, they have also to be observed from a teacher's and teacher educator's perspective. What benefit can they obtain from these learning strategies and the workshop method?

The research indicates that students and teachers are rather unanimous about their needs to master learning strategies. Consensus also appears when speaking for intensive courses in learning and striving towards a shared goal. This pattern of professional development is significant not only for students but for teachers' pedagogical knowledge enabling them to engage in the construction of their professional identity (Nissilä \& Virkkula, 2015; Virkkula \& Nissilä, 2014). Concerning music teachers, there is always difficulty in determining whether they are more educators than they are artists.

A significant observation comes from cross-professional collaboration. The professional musicians who participated in the project represented the same profession, but not the same instruments as the students. In that sense, the workshops offered cross-professional collaboration. This study emphasises the outcomes of changing relationships between educational experts and practitioners. The regular teachers, students, and professional musicians negotiated their tasks and especially students' learning objectives to reach the shared aim. Though the choices were successful in this project, in the future it will again be important to negotiate about the visitors' tasks, the focus of action and the expected outcomes. Collaborative processes between students, teachers, and visitors, including teacher trainers, added mutual trust and personal self-confidence in these cases and, thus, offer an interesting theme for investigation.

The findings show the great workload that the music students were willing to take. It concerned also the professional musicians who accepted their roles as mentors in addition to their regular work. The process showed shared ethos of the trade and the persons concerned. It also revealed the joy of playing, which is often lacking in strictly planned instrumental studies. Whether the studies concentrate on removing defects or enhancing musical expression depends on the cultural environment. In this process, the participants found a treasure.

In addition to learning to learn, the profitable use of workshops can be availed of in changing activities and in efforts to make processes better, flexible, and faster. It is about principles, rules, and concepts - not just tools. Learning through experiences and dialogue should be encouraged. 


\section{References}

Anderson, A., Howe, C., Soden, R., Halliday, J., \& Lowe, J. (2001). Peer interaction and the learning of critical thinking skills in further education students. Instructional Science, 29(1), 1-32.

Bagozzi, R. P. (1992). The Self-Regulation of Attitudes, Intentions, and Behavior. Social Psychology

Quarterly, 55(2), 178-204.

Bandura, A. (1986). Social foundations of thought and action. Upper Saddle River, NJ: Prentice Hall.

Bandura, A. (1994). Self-efficacy. In V. S. Ramachaudran (Ed.), Encyclopedia of human behavior (pp.

71-81). New York: Academic Press

Barrel, J. (1995). Critical issue: working toward student self-direction and personal efficacy as

educational goals. North Central Regional Educational Laboratory. Retrieved from http://www.ncrel.

org/sdrs/areas/issues/students/learning/lr2oo.htm

Baumeister,R. F., Bratslavsky, E., Muraven M., \& Tice, D. M. (1998). Ego Depletion: Is the Active Self

a Limited Resource? Journal of Personality and Social Psychology, 74(5) 1252-1265.

Biggs, J., \& Tang, C. (2011). Teaching for Quality Learning at University. Buckingham: Open

University Press/McGraw Hill.

Bower, G. H. (1970). Mental imagery and associative learning. In L. Gregg (Ed.), Cognition in

learning and memory (pp. 51-88). New York: Wiley.

Brown, J. S., Collins, A., \& Duguid, P. (1989). Situated cognition and the culture of learning.

Educational Researcher, 18(1), 32-41.

Deci, E., \& Ryan, R. (1985). The general causality orientations scale: Self-determination in personality. Journal of Research in Personality, 19(2), 109-134.

Deci, E., \& Ryan, R. (2014). The importance of universal psychological needs for understanding in the motivation workplace. In M. Gagné (Ed.), The Oxford handbook of work engagement, motivation, and self-determination theory (pp. 13-32). Oxford, UK: Oxford University Press.

Dweck, C. (1999). Self-theories: Their Role in Motivation, Personality, and Development. Philadelphia: Psychology Press.

Emmons, R. A. (1986). Personal strivings: An approach to personality and subjective well-being. Journal of Personality and Social Psychology, 51(5), 1058-1068.

Facione, P., \& Gittens C. A. (2011). Think critically. Boston: Pearson.

Flavell, J. H. (1979). Metacognition and cognitive monitoring: A new area of cognitivedevelopmental inquiry. American Psychologist, 34(10), 906-911.

Flavell, J. H. (1987). Speculations about the nature and development of metacognition. In F. E.

Weinert, \& R. H. Kluwe (Eds.), Metacognition, motivation and understanding (pp. 21-29). Hillsdale,

NJ: Erlbaum.

Flavell, J. H., Miller, P. H., \& Miller, S. A. (1993). Cognitive Development. (3rd ed.). Englewood Cliffs, NJ: Prentice Hall.

Heaton, R., \& Lampert, M. (1993). Learning to hear voices: inventing a new pedagogy of teacher education. In D. Cohen, M. McLaughlin, \& J. Talbert (Eds.), Teaching for Understanding: challenges 
for practice, research and policy (pp. 43-83). San Francisco: Jossey Bass.

Hickey, D. T. (1997). Motivation and contemporary socio-constructivist instructional perspectives.

Educational Psychologist, 32(3), 175-193.

Hickey, D. T., \& Zuiker, S. J. (2012). Multi-level assessment for discourse, understanding, and achievement in innovative learning contexts. The Journal of the Learning Sciences, 22(4), 1-65. Huitt, W. (1996). The mind. Educational Psychology Interactive. Valdosta, GA: Valdosta State University. Retrieved from http://www.edpsycinteractive.org/topics/summary/mind.html Kane, R. (1985). Free will and values. Albany: State University of New York Press.

Lave, J., \& Wenger, E. (1991). Situated Learning: legitimate peripheral participation. Cambridge: Cambridge University Press.

Lebler, D. (2008). Popular music pedagogy: peer learning in practice. Music education research, 1o(2), 193-213.

Lublin, J. (2003). Deep, surface and strategic approaches to learning. Dublin: Centre for Teaching and Learning.

Macaro, E. (2006). Strategies for language learning and for language use: Revising the theoretical framework. Modern Language Journal, 9o(3), 320-337.

Macaro, E. (2010). The relationship between strategic behaviour and language learning success. In

E. Macaro (Ed.), Continuum Companion to Second Language Acquisition (pp. 268-299). London: Continuum.

Mischel, W. (1996). From good intentions to willpower. In P. Gollwitzer, \& J. Bargh (Eds.), The psychology of action (pp. 197-218). New York: Guilford Press.

Moschovich, J. N., \& Brenner, M. (2000). Integrating a naturalistic paradigm into research on mathematics and science cognition and learning. In R. Lesh, \& A. Kelly (Eds.), Handbook of Research Design in Mathematics \& Science Education (pp. 457-489). Lawrence Erlbaum Associates, Inc: New Jersey.

Nissilä, S-P. (1999). Reflective practice in teacher education and the need of autonomy. In A.

Camilleri (Ed.), Introducing Learner Autonomy in Teacher Education (pp. 9-15). Strassbourg: Council of Europe Publishing.

Nissilä, S-P, 2010. Dynamic Dialogue in Learning and Teaching. Saarbrucken. Germany: VDM

Publishing House Ltd.

Nissilä, S-P., \& Virkkula, E. (2015). Problem solution processes of musicians and engineers: what do their approaches look like? Journal of Problem Based Learning in Higher Education, 3(1), 98-117.

Oxford, R. L. (1990). Language Learning Strategies: What Every Teacher Should Know. Boston: Heinle \& Heinle.

Paivio, A. (1969). Mental imagery in associative learning and memory. Psychological Review, 76(3), 241-263.

Paivio, A (1971). Imagery and verbal processes. New York: Holt, Rinehart and Winston. Patton, M. (1990). Qualitative evaluation and research methods. Newbury Park, CA: Sage.

Pintrich, P. R., \& McKeachie, W. (200o). A framework for conceptualizing student motivation and 
relf-regulated learning in the college classroom. In P. R. Pintrich, \& P. Ruohotie (Eds.), Conative Constructs and Self-Regulated Learning (pp. 31-50). Hämeenlinna: Research Centre for Vocational Education.

Roberts, M. J., \& Erdos, G. (1993). Strategy selection and metacognition. Educational Psychology 13(3-4), 259-266.

Rose, H. (2012). Reconceptualizing strategic learning in the face of self-regulation: Throwing language learning strategies out with the bathwater. Applied Linguistics, 33(1), 92-98.

Ruohotie, P. 200o. Conative Constructs in Learning. In P. Pintrich, \& P. Ruohotie (Eds.), Conative Constructs and Self-Regulated Learning (pp. 1-30). Hämeenlinna, Finland: Research Centre for Vocational Education.

Soden, R., \& Pithers, R. T. (2001). Knowledge Matters in Vocational Problem-Solving: a cognitive view. Journal of Vocational Education and Training, 53(2), 205-222.

Schön, D. (1987). Educating the reflective practitioner: Toward a new design for teaching and learning in the professions. San Francisco: Jossey-Bass.

Tallon, A. (1997). Head and heart: Affection, cognition, volition as triune consciousness. New York: Fordham University

Tiruneh, D. T., Verburgh, A., \& Elen, J. (2014). Effectiveness of Critical Thinking Instruction in Higher Education: A Systematic Review of Intervention Studies. Higher Education Studies, 4(1), 1-17. Virkkula, E. (2016a). Communities of Practice in the Conservatory: Learning with a professional musician. British Journal of Music Education, 33(1), 27-42.

Virkkula, E. (2016b). Informal in formal: The relationship of informal and formal learning in popular and jazz music master workshops in conservatoires. International Journal of Music Education, 34(2), $171-185$.

Virkkula, E. (2017). The joy of playing shone from all members of the band: The motivational factors in conservatory master workshops. Submitted manuscript.

Virkkula,E., \& Nissilä, S-P. (2014). In-service Teachers' Learning Through Integrating Theory and Practice. Sage Open Journal, 4(4), 1-8.

Weinstein, C. E., Zimmerman, S. A., \& Palmer, D. R. (1988). Assessing Learning strategies: The design and development of the LASSI. In C. E. T. Goetz, \& W. P. A. Alexander (Eds.), Learning and study strategies: Issues in assessment, instruction and evaluation (pp. 25-40). San Diego, CA: Academic Press.

Wenger, E. (1998). Communities of practice: Learning, meaning and identity. Cambridge, UK:

Cambridge University Press.

William, D., \& Thompson, M. (2008). Integrating assessment with instruction: What will it take to make it work? In C. A. Dwyer (Ed.), The future of assessment: Shaping teaching and learning (pp. 53-82). Mahwah, NJ: Lawrence Erlbaum Associates.

Wood G. (1967). Mnemonic systems in recall. Journal of Educational Psychology, 58(6), 1-27. 


\section{Biographical note}

Esa Virkкula, PhD, has been a teacher and musician since 1991. He has planned and implemented many popular and jazz music-training programs at various levels of education. He worked as a director of education of pop and jazz music in The Music Conservatory of Oulu in 2000-2011, and now works as a Principal Lecturer in Oulu University of Applied Sciences, School of Vocational Teacher Education. Virkkula's research interests have been cooperation of educational institutions and work life, socio-cultural learning and most recently competence-based education. These themes he has dealt with in his teaching, post-doctoral research, conference presentations and journal articles. As a musician, Virkkula has performed with a number of respected artists, e.g. Randy Brecker, Tim Hagans, Victoria Tolstoy and Dr. Lonnie Smith.

SÄDE-Pirkкo Nissil $\ddot{A}, \mathrm{PhD}, \mathrm{MA}$, is newly retired from Principal Lecturer's post in Oulu University of Applied Sciences after a long career as a language teacher and teacher educator. Since 2010 she has worked in projects as the trainer of mentors, heads of schools and school communities. She got interested in research when participating as Finland's representative in the projects of Council of Europe, which preceded the EU. Since then she has worked in several international and national development projects. After retiring (2017) she works as an alumnus in vocational teacher education and promotes projects through her enterprise. She is interested in the phenomena of learning, teacher development and supporting the growth of teachers' personal and professional identities. In her doctoral thesis (2006) she dealt with the development of pedagogical thinking of adult, highly educated students. 


\section{Appendix 1}

Music students' self-assessed strategies: a classification according to R. Oxford's (1990) taxonomy

\begin{tabular}{|c|c|c|c|c|c|c|c|}
\hline \multicolumn{8}{|c|}{ DIRECT STRATEGIES } \\
\hline Code & I Memory St & ategies & & & & & \\
\hline MS 1 & a) grouping & $\begin{array}{l}\text { b) associat- } \\
\text { ing }\end{array}$ & $\begin{array}{l}\text { c) replacing } \\
\text { earlier learnt } \\
\text { habits with } \\
\text { new }\end{array}$ & & & & \\
\hline MS 2 & $\begin{array}{l}\text { a) using } \\
\text { imagery }\end{array}$ & $\begin{array}{l}\text { b) musical } \\
\text { mapping }\end{array}$ & $\begin{array}{l}\text { c) using key } \\
\text { triggers }\end{array}$ & $\begin{array}{l}\text { d) repre- } \\
\text { senting } \\
\text { sounds in } \\
\text { memory }\end{array}$ & & & \\
\hline MS 3 & $\begin{array}{l}\text { a) struc- } \\
\text { tured } \\
\text { reviewing }\end{array}$ & $\begin{array}{l}\text { b) structured } \\
\text { arranging } \\
\text { music }\end{array}$ & & & & & \\
\hline MS 4 & $\begin{array}{l}\text { a) using } \\
\text { physical } \\
\text { sensation }\end{array}$ & $\begin{array}{l}\text { b) using } \\
\text { mechanical } \\
\text { techniques }\end{array}$ & & & & & \\
\hline Code & \multicolumn{7}{|c|}{ II Cognitive Strategies } \\
\hline CS 1 & $\begin{array}{l}\text { a) Repeat- } \\
\text { ing }\end{array}$ & $\begin{array}{l}\text { b) formally } \\
\text { practicing } \\
\text { with sounds } \\
\text { \& training }\end{array}$ & $\begin{array}{l}\text { c) recogniz- } \\
\text { ing formulas } \\
\text { and patterns }\end{array}$ & $\begin{array}{l}\text { d) recom- } \\
\text { bining or } \\
\text { compos- } \\
\text { ing own } \\
\text { music }\end{array}$ & $\begin{array}{l}\text { e) practicing } \\
\text { naturalistically }\end{array}$ & & \\
\hline CS 2 & $\begin{array}{l}\text { a) getting } \\
\text { the idea } \\
\text { quickly }\end{array}$ & $\begin{array}{l}\text { b) using } \\
\text { resources for } \\
\text { communica- } \\
\text { tion through } \\
\text { music }\end{array}$ & & & & & \\
\hline $\operatorname{CS} 3$ & $\begin{array}{l}\text { a) reason- } \\
\text { ing deduc- } \\
\text { tively }\end{array}$ & $\begin{array}{l}\text { b) analysing } \\
\text { expressions }\end{array}$ & $\begin{array}{l}\text { c) analysing } \\
\text { contrastively } \\
\text { (across mod- } \\
\text { els) }\end{array}$ & $\begin{array}{l}\text { d) } \\
\text { translat- } \\
\text { ing music } \\
\text { expres- } \\
\text { sions to } \\
\text { meanings }\end{array}$ & $\begin{array}{l}\text { e) transfer- } \\
\text { ring (one skill/ } \\
\text { expression/ } \\
\text { tradition to } \\
\text { another) }\end{array}$ & $\begin{array}{l}\text { f) com- } \\
\text { posing }\end{array}$ & \\
\hline CS 4 & $\begin{array}{l}\text { a) taking } \\
\text { notes }\end{array}$ & $\begin{array}{l}\text { b) summa- } \\
\text { rizing }\end{array}$ & $\begin{array}{l}\text { c) highlight- } \\
\text { ing }\end{array}$ & & & & \\
\hline Code & \multicolumn{7}{|c|}{ III Compensation Strategies } \\
\hline $\mathrm{C} 1$ & $\begin{array}{l}\text { a) using } \\
\text { clues from } \\
\text { music }\end{array}$ & $\begin{array}{l}\text { b) using } \\
\text { clues from } \\
\text { personal } \\
\text { experience }\end{array}$ & & & & & \\
\hline C 2 & $\begin{array}{l}\text { a) switching } \\
\text { to familiar } \\
\text { ways of pre- } \\
\text { sentation }\end{array}$ & $\begin{array}{l}\text { b) getting } \\
\text { help }\end{array}$ & $\begin{array}{l}\text { c) avoiding } \\
\text { playing } \\
\text { partially or } \\
\text { totally }\end{array}$ & $\begin{array}{l}\text { d) select- } \\
\text { ing the } \\
\text { topic }\end{array}$ & $\begin{array}{l}\text { e) adjusting } \\
\text { playing }\end{array}$ & $\begin{array}{l}\text { f) clever inven- } \\
\text { tions }\end{array}$ & $\begin{array}{l}\text { g) para- } \\
\text { phrasing }\end{array}$ \\
\hline
\end{tabular}




\begin{tabular}{|c|c|c|c|c|c|c|}
\hline \multicolumn{7}{|c|}{ INDIRECT STRATEGIES } \\
\hline \multirow{2}{*}{$\begin{array}{l}\text { Code } \\
\text { MES } 1\end{array}$} & \multicolumn{6}{|c|}{ I Metacognitive Strategies } \\
\hline & $\begin{array}{l}\text { a) over- } \\
\text { viewing } \\
\text { and linking } \\
\text { with already } \\
\text { known } \\
\text { material }\end{array}$ & $\begin{array}{l}\text { b) paying } \\
\text { attention }\end{array}$ & $\begin{array}{l}\text { c) delaying } \\
\text { expression } \\
\text { to focus on } \\
\text { listening }\end{array}$ & & & \\
\hline MES 2 & $\begin{array}{l}\text { a) finding } \\
\text { out about } \\
\text { music learn- } \\
\text { ing }\end{array}$ & $\begin{array}{l}\text { b) organiz- } \\
\text { ing learning }\end{array}$ & $\begin{array}{l}\text { c) setting } \\
\text { goals and } \\
\text { objectives }\end{array}$ & $\begin{array}{l}\text { d) identi- } \\
\text { fying the } \\
\text { purpose of } \\
\text { the task }\end{array}$ & $\begin{array}{l}\text { e) plan- } \\
\text { ning } \\
\text { for the } \\
\text { presenta- } \\
\text { tion of the } \\
\text { task }\end{array}$ & $\begin{array}{l}\text { f) seeking op- } \\
\text { portunities to } \\
\text { practice in or } \\
\text { for work life }\end{array}$ \\
\hline
\end{tabular}

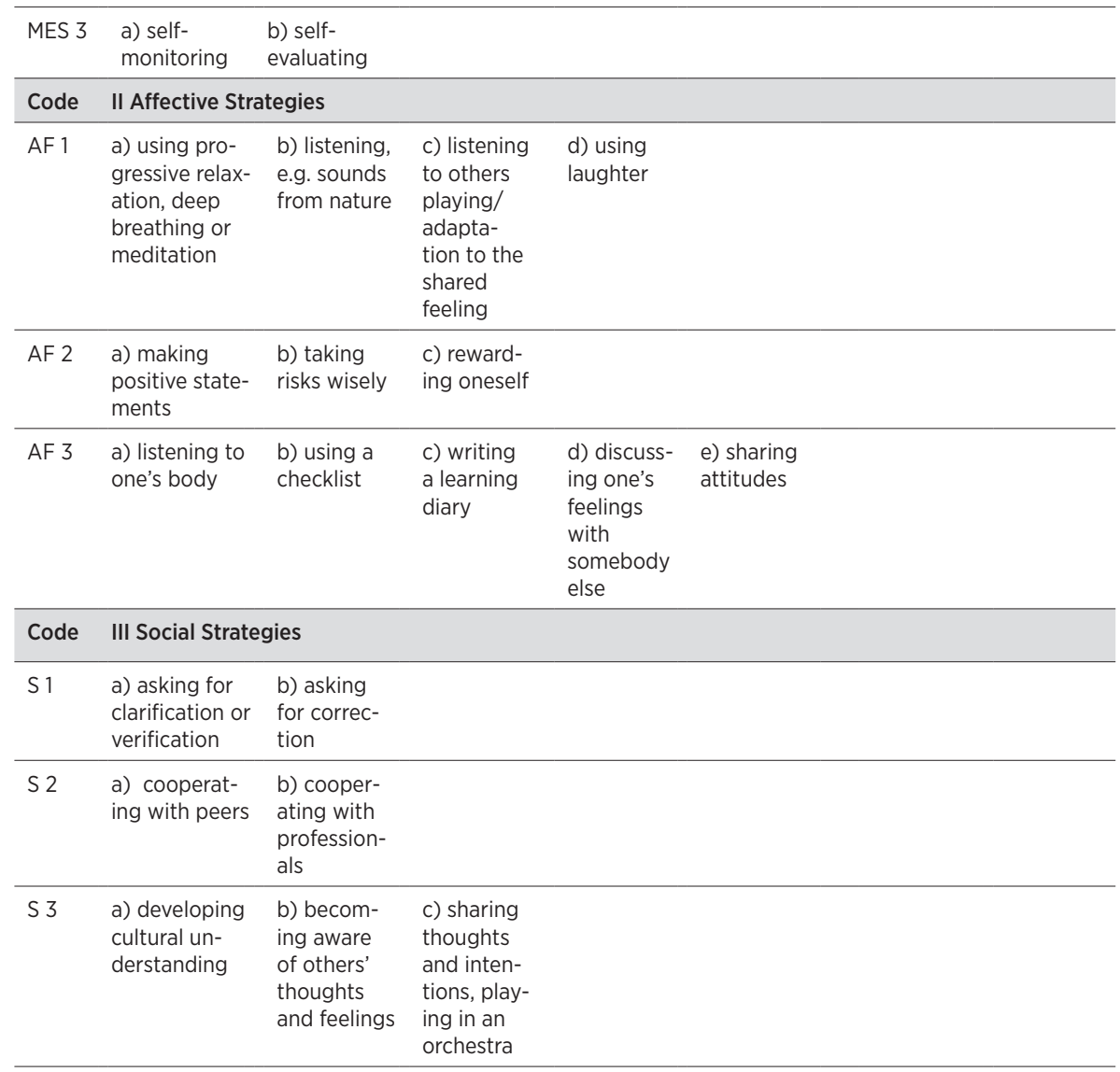

